\title{
The use of 3D printing technologies in art casting
}

\author{
Zastosowanie druku 3D w odlewnictwie artystycznym
}

\section{ALEKSANDRA MIKULÍKOVÁ MAREK WYLEŻOŁ*}

DOI: https://doi.org/10.17814/mechanik.2020.5-6.12

\begin{abstract}
The paper presents one of the roles of additive manufacturing used for preparing an art casting. Based on the virtual model (CAD), a casting pattern was 3D printed, based on which the wax pattern was made and in the final step an art casting was made.
\end{abstract}

KEYWORDS: 3D printing, lost-wax method, art casting

W artykule zaprezentowano przykład zastosowania technologii druku 3D w odlewnictwie artystycznym. Opisany proces bazuje na przygotowaniu wirtualnego modelu CAD, następnie na jego podstawie wydrukowany zostaje model 3D, który służy jako wzór do wytworzenia modeli woskowych, a w ostatnim etapie - odlewu artystycznego.

SŁOWA KLUCZOWE: druk 3D, metoda traconego wosku, odlewnictwo artystyczne

\section{Introduction}

Additive manufacturing is mostly used in rapid prototyping as a cost-effective way to communicate ideas visually. Rapid prototyping coupled with 3D printing encourages the use of multiple iterations of an item during its development. This often promotes the development of a final product with desirable design refinements. Such a product may more perfectly meet user expectations, lifespan goals and budgetary requirements. Foundry engineering is another field where additive manufacturing is used. 3D printing enables printing of patterns direct without making moulds, what reduces the metal casting process steps and the total cost of the process. There is also another field where using of 3D printing technologies is more and more popular - art casting process. 3D printed patterns replace traditional patterns (hand made from clay, wood etc.) and enable to reach difficult shapes and to reduce the time of the whole process of producing the art casting.

\section{Art casting technologies}

Art castings can be produced by many technologies. The most common technologies to produce the art casting are sand casting, lost-wax casting (investment casting), Shaw casting, die-casting $[4,6]$.

The most proper of these technologies to realize the aim of the research was the lost-wax casting $[1,3,5]$. Lost-wax casting is the most proper from many the process of choice because it is extremely accurate in replicating details and because of the durability of the objects it creates. However, the process is very arduous and time-consuming. Lost-wax casting is often used for casting of sculptures, figures, jewellery, machines parts and elements which demand high precision. Variations of the process include: "lost mould", which recognizes that materials other than wax can be used (such as: tallow, resin, tar, and textile); and "waste wax process" (or "waste mould casting"), because the mould is destroyed to remove the cast item. Casts can be made of the wax model itself, the direct method, or of a wax copy of a model that need not be of wax, the indirect method $[4,8]$.

Lost-wax castings are characterized by low mass (from few grams to few kilograms), high dimensions accuracy, low surface roughness, possibility to obtain complicated shape and thin walls $[7,9]$.

\section{The aim of the research}

The aim of the research was to create an art casting statue using computer aided design (CAD), additive manufacturing (3D printing) and casting technologies. The project was inspired by logo of Students Research Group "Sferoid" with additional Voronoi pattern [12].

\section{Inspiration}

The main inspiration to create the model was the logo of Students Research Group "Sferoid" from Foundry Department at Silesian University of Technology in Gliwice (fig. 1a) [10]. The logo shows a spline shaft shape, which is a symbol of Silesian University of Technology. Hexagons inside the spline shaft have also a meaning and they symbolize the crystal structure of nodular graphite (hexagonal unit cell). The name of the Research Group "Sferoid" comes from a nodular graphite, which in polish language is: "grafit sferoidalny". Another inspiration to create a model was also a Voronoi pattern which is usually used for: maximizing thermal comfort and mechanical stiffness (for example - 3D printable orthopaedic cast) and creating an object more visually appealing (fashion, jewellery). In that case the Voronoi pattern was used for the aesthetic aspect (art casting) and to check the casting methods ability to recreate the pattern.

\footnotetext{
* Mgrinż.Aleksandra Mikulíková, aleksandra.mikulikova@polsl.pl,https://orcid.org/0000-0001-9259-128X-Politechnika Śląska, Gliwice, Polska

Dr hab. inż. Marek Wyleżoł, prof. PŚ, marek.wylezol@polsl.pl, https://orcid.org/0000-0001-6324-510X - Politechnika Śląska, Gliwice, Polska
} 


\section{The scope of the research}

The research included the whole art casting producing process based on 3D printed model. The final statue was a bronze casting situated on a granite base. The statues were awarded as a prize for the best presentations on 15th Seminar of Students Research Group "Sferoid".

\section{Virtual model}

The virtual model was created by use of Autodesk Inventor 2019 system (the project included foundry engineering requirements as wall inclination). The physical model was created by two 3D printing methods: Fused Deposition Material technology (with the use of ABS material) and Digital Light Processing technology (light curing resin) [2]. Prints were produced in two sizes:

- two-sided print from a resin with maximum diameter $80 \mathrm{~mm}$ - as a concept model;

- one-sided print from ABS with maximum diameter $125 \mathrm{~mm}$.

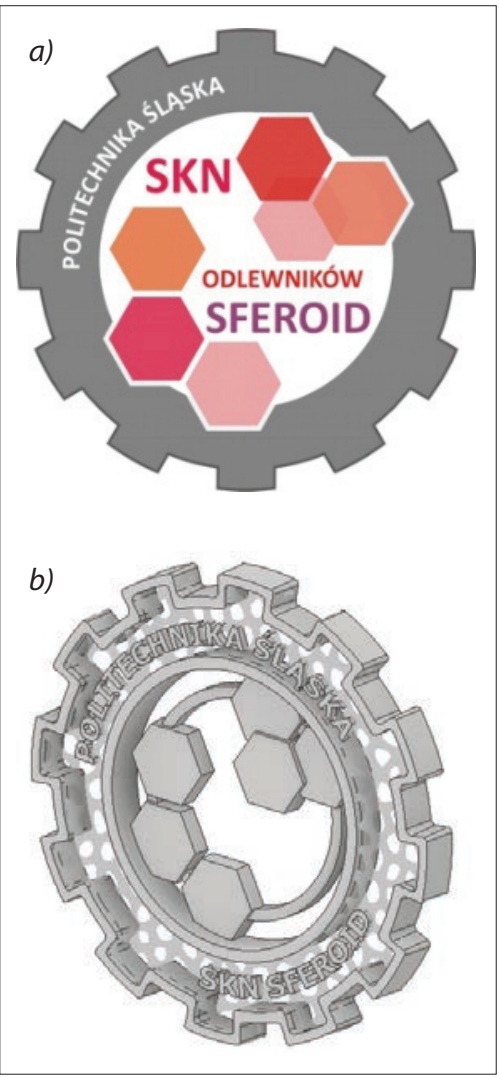

Fig. 1. The original logo of SKN "Sferoid" $(a)$ and a virtual model $(b)$

\section{D printed pattern (DLP and FDM)}

Digital Light Processing (DLP) is a 3D printing process that works with photopolymers. DLP uses a conventional light source - arc lamp with a liquid crystal display panel which is applied to the entire surface of the vat of photopolymer resin in a single pass. DLP produces highly accurate parts with excellent resolution and because of that DLP is using in medicine, jewellery and electronic industries. In this process, once the 3D model is sent to the printer, a container of liquid polymer is exposed to light from a DLP projector under safelight conditions. The DLP projector displays the image of the 3D model onto the liquid polymer. The exposed liquid polymer hardens, and the build plate moves down and the liquid polymer is once more exposed to light. The process is repeated until the 3D model is complete and the container is empty of liquid, revealing the solidified model [2].

The physical 3D model of the created virtual model was printed by using Anycubic Photon printer. The build volume for the Anycubic Photon DLP 3D printer is $115 \times 65 \times 155 \mathrm{~mm}$, which is quite small compared to other machines. The material used for printing was liquid resin (Resin White) from Monocure 3D [11]. Printing time took 10 hours. Post-processing involved washing the model with ethanol, curing them, cleaning the build plate. The model had no support elements to remove. Its surface was smooth enough to continue the process without any other treatment.

Fused deposition modelling (FDM) is another Additive Manufacturing process developed in the 1980s. It uses thermoplastic filaments as build materials. The selected filament is heated to the point that it can be extruded onto the print bed one layer at a time. As it cools, it fuses to the preceding layer. Faster FDM machines lay down thicker plastic layers that may lack dimensional accuracy, although slower machines that lay down thin, more accurate layers are materializing. Thermoplastics like ABS are amenable to sanding, drilling and machining during postprocessing [2].

The final 3D printed model was made using FDM method because of the bigger build area of the FDM printer. The model was printed from ABS (Acrylonitrile Butadiene Styrene - thermoplastic polymer) using Zortrax M200 printer. With a $200 \times 200 \times 185 \mathrm{~mm}$ build area that includes a perforated build platform for mitigating the material's tendency to warp, the printer is optimized for print with ABS. Printed time of the model was 15 hours with using layer thickness $-0,09 \mathrm{~mm}$. There were many visible layers on the surface of the final printed pattern. Post-processing included support removal and acetone smoothing.

Considering advantages and disadvantages of different art casting methods, the lost-wax method was chosen. The 3D printed resin pattern was used as a concept model because of its small size. The 3D print from $\mathrm{ABS}$ was selected as a final model and used for creating the wax pattern (maximum diameter $125 \mathrm{~mm}$ ). The final statues were meant to be made from bronze.
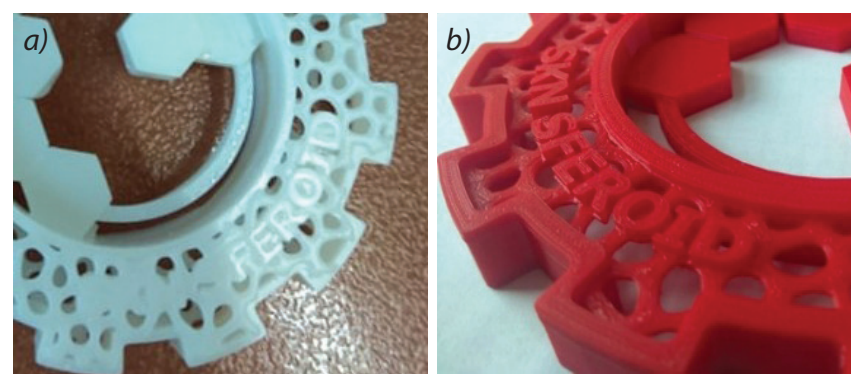

Fig. 2. Resin 3D print (a), ABS 3D print (b) 


\section{Results of the research}

After selection of casting technology and material type, there were conducted few (four) casting tests. Lost-wax casting process started from model-making (3D printed pattern with $\mathrm{ABS}$ ), then mould making negative of the original model. The mould was made with silicone mass Novosil B. Solidification time for the silicone mould was $60 \mathrm{~min}$. Then the 3D printed pattern was removed and the entire mould was poured with molten wax (wax Castaldo, pouring temperature $74^{\circ} \mathrm{C}$ ) and let it cool and solidify (40 min). The mould could be reused to make multiple copies, limited only by the durability of the mould.
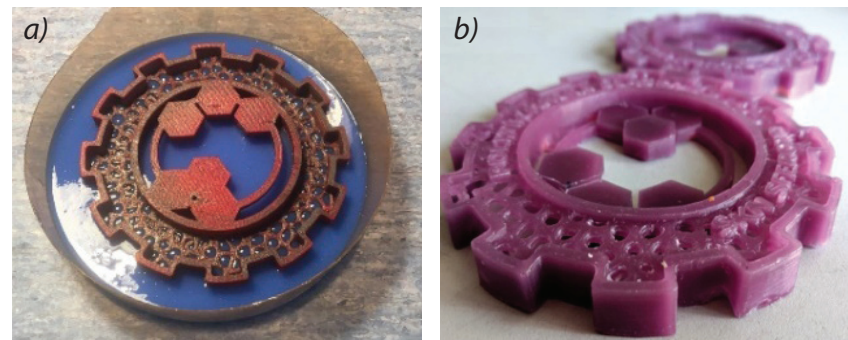

Fig. 3. ABS printed pattern in silicone mould (a), wax models (b)

Another important thing to do was to choose the proper gating system and casting position. The gating system is composed of pouring basin, sprue, runner, gates and risers which were replaced by wax cylinders. The ready wax pattern was combined with the other structure of wax (cylinders) which provide paths for the molten metal to flow and for air to escape. Based on the experiments and knowledge it was decided to place the wax pattern horizontally and central under the main sprue (fig. $4 b$ ).
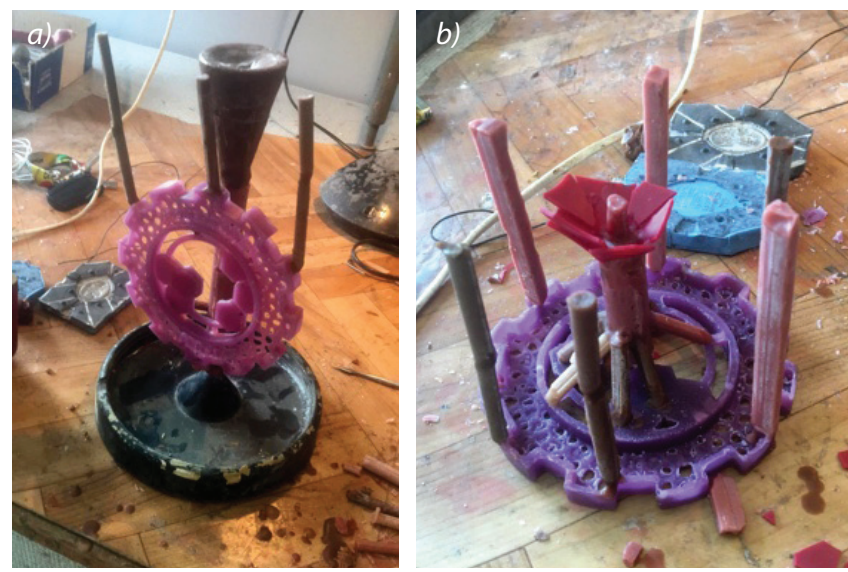

Fig. 4. Gating system position with wax patterns placed perpendicullary $(a)$ and horizontally $(b)$

Then, the whole wax construction was placed in the special fireproof metal bucket and poured by gypsum mass (casting gypsum GoldStar). The whole piece was placed cup-down in a kiln, whose heat hardened the silica mass into a metal bucket, and the wax melted and ran out. If the ceramic mass was left to cool down, it had to be reheated before the pouring. Then melted metal was poured carefully into the hot ceramic mass.
After cooling process, the ceramic mass was hammered releasing the rough casting. The sprues were cut off. The casting was worked until it looked like the original model.
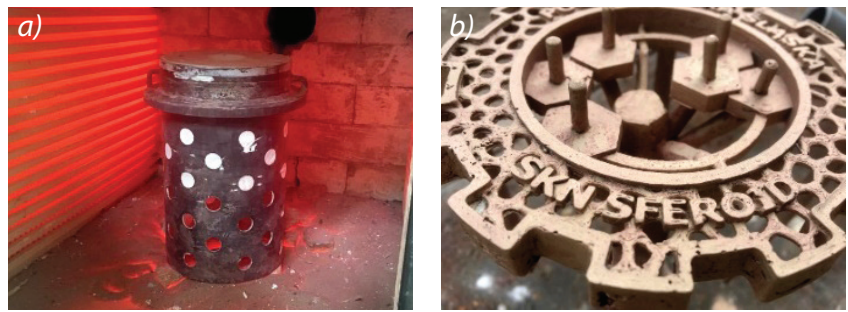

Fig. 5. Heating in the kiln (a), bronze casting with risers (b)

\section{Results}

The lost-wax method was very time-consuming process. Preparation of the wax patterns took a lot of time (12 hours). Also, the cost of that process was not the cheap one in comparison to other casting methods. Compared all casting tests there were noticed that better results are achieved by using horizontally position of the model. The best front surface condition was achieved with using risers on every hexagons' surface. In that case, postprocessing took only a while ( 2 hours). The main differences between model with risers (used on the hexagons) and without are shown on the fig. 6 . The model without risers on the central surfaces has got many small holes (pores) caused by air caught inside the mould.

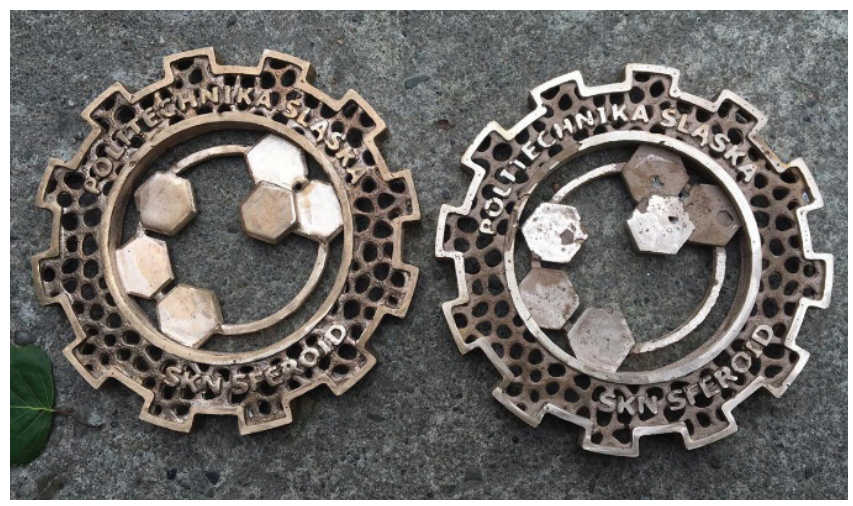

Fig. 6. Comparison of the results: $a$ ) casting made with risers in the middle of the model, $b$ ) casting with the risers used only on the edges

\section{Summary and conclusions}

In the end of the whole statue-making process and after analysis of the results, there was concluded that: - 3D printing is a great alternative to traditional art casting patterns methods (clay, gypsum, wood sculpture), because it is less time-consuming, costless and it allows people with no manual skills (carving, sculpting) to create artistic forms by using the computer aided-design methods (CAD). Combination of CAD and $3 \mathrm{D}$ printing allows using the methods based on the algorithms (like a Voronoi pattern) to achieve the original shape of the final print. This enable also printing the concept models and selection of the best one. 


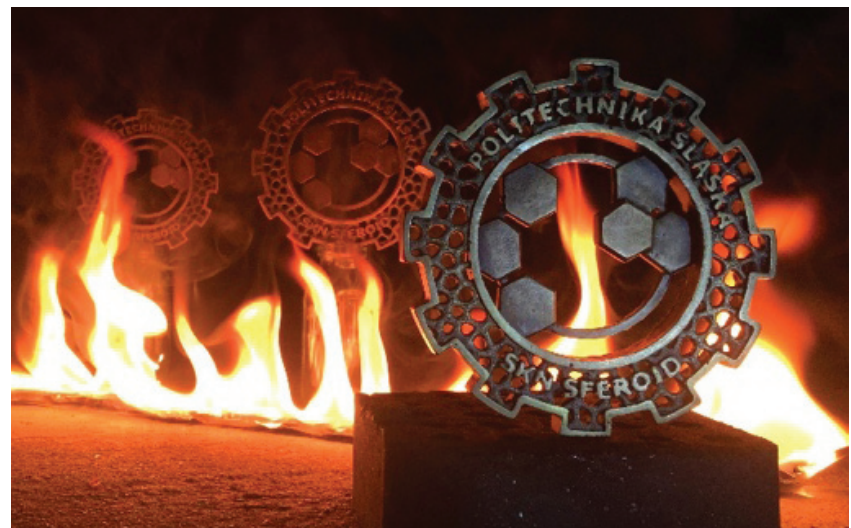

Fig. 7. Final bronze statues (artistic presentation)

- Selected method (lost-wax casting) was a proper choice to produce a bronze statue from a 3D printed pattern. The silicone mould enabled to reproduce a complicated shape of the Voronoi pattern. The silicone mould was accurate as much that 3D printed layers was also reproduced on the wax pattern.

- The best result of the final bronze casting was achieved after using the horizontally position of the casting under the central-placed sprue (gating system) and using the risers on every flat surface (hexagons).

\section{REFERENCES}

[1] Branny Ł. „Druk 3D w odlewaniu metoda wytapianych modeli”. Zeszyty Studenckich Prac Naukowych „SFEROID”. 19 (2017): 25-30.

[2] Budzik G., Siemiński P. „Techniki przyrostowe. Druk 3D. Drukarki 3D". Warsaw: Wydawnictwo OWPW, 2015.

[3] Dziwoki A., Michalski A., Cholewa M. „Wykonanie modelu odlewniczego gipsowego na podstawie rzeźby glinianej”. Zeszyty Studenckich Prac Naukowych „SFEROID”. 19 (2017): 57-64.

[4] Gawroński J. et al. „Odlewnictwo artystyczne. Formowanie i odlewanie w sztuczkach oraz metoda wytapianych modeli". Gliwice: Wydawnictwo Politechniki Śląskiej, 2013.

[5] Konečná K., Lichý P. „Artistic casting - Allegory of Pride”. Zeszyty Studenckich Prac Naukowych „SFEROID”. 19 (2017): 101-104.

[6] Kosowski A. „Podstawy odlewnictwa”. Warsaw: Wydawnictwo Naukowe „Akapit”, 2001.

[7] Lewandowski L. „Masy formierskie i rdzeniowe”. Warsaw: Wydawnictwo Naukowe PWN, 1991.

[8] Modrzyński A. „Technologia odlewnictwa”. Poznań: Wydawnictwo Politechniki Poznańskiej, 2015.

[9] Perzyk M. et al. „Odlewnictwo”. Warsaw: Wydawnictwo WNT, 2012

[10] http://afe.polsl.pl/index.php/pl/page/show/77/seminarium-skn-odlewnikow-sferoid [accessed: 10 July 2019].

[11] https://monocure3d.com.au/Monocure-3D-White-Resin-RAPID-p/3dr-3583w-500b.htm [accessed: 15 July 2019].

[12] https://www.voronator.com [accessed: 20 July 2019].

This research was partially supported by Department of Foundry Engineering, Silesian University of Technology in Gliwice. We thank our colleagues from Department of Foundry Engineering who provided all materials and equipment for an art casting process. We thank Wojciech Karski, BSc - an author of photos on figs. 5-7, for assistance with lost-wax process and Bernard Czok for comments that greatly improved the work. 